\title{
Impact of Cross Training on Employee Skill Development and Career Growth using Prediction Monitoring System
}

\author{
S.Vasanthi,.S.Rabiyathul Basariya
}

\begin{abstract}
Cross training an employee means to train him in different rolls and activities in his same domain of job. Cross training is planned in an organization to improve inter positional knowledge of the employees. This will maintain positive coordination between different teams. Employees will learn the skills that are required to perform other rolls which helps to understand the overall picture of the work in the organization. This paper discusses different methods of cross training and their benefits to employees.
\end{abstract}

Keywords : Cross training, employee benefits, career growth, skill development.

\section{INTRODUCTION}

In small organizations where number of employees is less and multiple jobs to be done, every employee should be able to perform the jobs of other employees too. This will be helpful when other employees are ill or on vacation or quit the job with short notice. If the employees are cross-trained business will keep moving in such situations. Further learning different skill will help the employee to grow vertically in his career.

Irrespective of the size of the organisation, cross training is incredible beneficial for employee and employer. If it is a small organisation with limited employees, where employees may need to perform different roles and where as in a large company though everyone has a defined role, in case of absenteeism, unexpected leave etc cross trained employees will perform the roles of others and keep the business running. This article will discuss the planning of cross training in an organisation, how it helps for the skill development and career growth of employees.

\section{OBJECTIVES}

- To define cross training

- Planning cross training in an organisation

- To discuss the benefits cross training for the career growth of an employee

\section{METHODOLOGY}

Revised Manuscript Received on September 22, 2019.

S.Vasanthia Research Scholar, Bharath Institute of Higher Education and Research, Chennai.shakilasuraj@yahoo.com,

Dr.S.Rabiyathul Basariyab Associate Professor \& Research Supervisor, Bharath Institute of Higher Education and Research, Chennai.
A questionnaire containing questionsof how the cross training is beneficial or non-beneficial to employees is circulated among the employees of a manufacturing industry and their opinions are collected. The collected data is analysed using statistical methods and a conclusion is drawn.

\section{CROSS TRAINING}

Cross training is defined as learning more than one skill in the work place instead of performing a specific job. This will make the employee all-rounder in the organisation. An employee will work along with another employee and understands how the other person is performing his tasks. This method is based on the interest of the employee but not the management initiative. In case of management initiative, a proper planned program will be conducted for the employees to learn the skills of others.Cross training promotes adaptability and allows the teams to maintain good coordination among them.

Cross training is not only useful for employees but also to the company. Cross trained employees will become more valuable to the organisation as they have learnt more skills and enriched their jobs. They will be loyal to management as the organisation is investing time, money and resources for the development of employee career. Thus employees will gain recognition as their contribution towards the organizational growth will gradually increase.

\section{Planning an effective cross training program}

Cross training will reap benefits only if it is planned properly and implemented effectively. Otherwise the draw backs will be more than the advantages.

- Choose the right people to train. Employees who are interested in learning other skills are to be chosen for training. Learning capability of the people should also be considered while choosing them for training.

- Identify the tasks for which cross-training can be given

- Explain the team about the training benefits.

- Plan for the expenses and training facilities to accomplish the training

- Reduce the work load of the employees who are undergoing training. 
- Need for formal or informal training is to be assessed based on the nature of skill to be trained.

- Employees should be challenged to enrich the opportunities as part of training activities.

- Plan the production activities during training period such that the production will not get affected.

- Consider the intangible factors also while planning for cross training such as motivation of employee.

- Assure employees that the cross training is for helping them but not to replace the employees.

- Assess the feedback of the trained employees and look for the betterment of training methods.

- Make the employees to understand that the skills learnt from cross training will not be retained for ever but they have to utilize and have to be re trained periodically.

A well-planned cross training program will become a proactive plan to keep running the business successfully despite of employee absenteeism and loss of key employees.

\section{CAREER DEVELOPMENT}

Career development refer to the managing one's career either to enrich or to enlarge the career. It involves getting additional skills through training, taking of more responsibilities, moving up to a career in the same organization or in different organization. Career development not only helps the organisation but also to fulfil the needs of an employee too. Strategies to develop the career can be driven either by the organisation itself by implementing organisation policies or by the employee himself. Organisation can arrange for different types of training and other learning programs for the employees for employee growth. This will help in the long run for the career growth. Career development has become an essential part of any organisation as this will prevent the employee from job burnout, improves the quality of work life and helps the employee to achieve his work goals.

Employee can himself put efforts to learn different skills or attend trainings wherever possible to that helps him to move up in the career. He should set the goal, attain the skills accordingly, perform well in the current job and doing self-assessment are the major steps for career development.

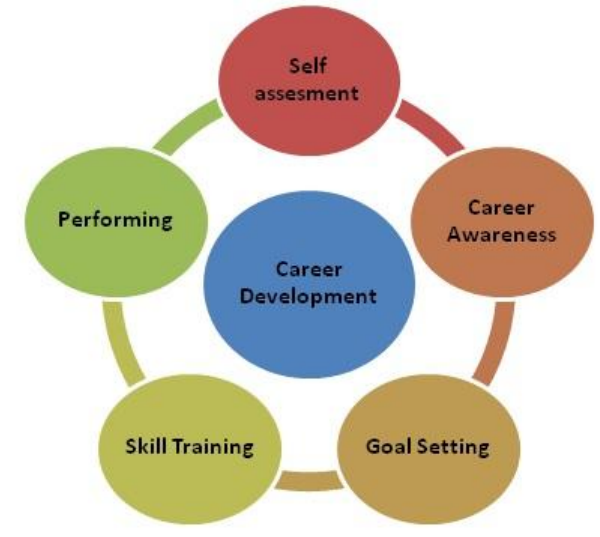

Fig1. Steps for Career development
One of the prominent training methods used by the organisation to help the employees to learn multiple skills is Cross-training.

Cross training anemployee enables him to learn additional skills. Learning new skill make him more valuable. This will also reduce their boredom and keep them stimulated. Further, the cross training will provide the following benefits to the employees that help them to grow in their career. When an employee is given more responsibilities, he feels that the management trusts him and willing to put more efforts. This will help him to grow professionally.

- Employee will get awareness of his roles and functions in the organisation.

- Knowledge towards their job functions will be improved.

- Employee will understand where his role fits and will have a better perspective and thus opportunities for career advancement will be increased.

\section{STATISTICAL ANALYSIS}

A questionnaire is circulated among the employees of an electronic manufacturing services organisation where around 1000 employees are working. Answered questionnaire is evaluated and found that 235 employees have answered all the questions in the questionnaire. The response of the employees is tabulated in the table below. The same is represented in the chart 1.1.

\begin{tabular}{|c|l|c|c|}
\hline S.No & $\begin{array}{c}\text { Level of } \\
\text { Agreement }\end{array}$ & $\begin{array}{c}\text { Number of } \\
\text { Respondents }\end{array}$ & $\begin{array}{c}\text { Percentage } \\
\text { \% }\end{array}$ \\
\hline 1 & $\begin{array}{l}\text { Strongly } \\
\text { Disagree }\end{array}$ & 6 & 2.55 \\
\hline 2 & Disagree & 21 & 8.94 \\
\hline 3 & Not Sure & 60 & 25.53 \\
\hline 4 & Agree & 86 & 36.60 \\
\hline 5 & Strongly Agree & 62 & 26.38 \\
\hline & Total & $\mathbf{2 3 5}$ & $\mathbf{1 0 0}$ \\
\hline
\end{tabular}

Source: Primary Data

Table 1.1 Responses of employees

\section{Analysis of Responses}

The above table 1.1 depicts that 2.55 percent of respondents strongly disagree that the cross training is beneficial to employee. 8.94 percent of respondents disagree that the cross training is beneficial to employee. 25.53 percent of respondents are not sure that the cross training is beneficial to employee. 36.60 percent of respondents are agree that the cross training is beneficial to employee. 26.38 percent of respondents strongly agree that the cross training is beneficial to employee.Majority of the respondents agree that the cross training is beneficial to employee. 


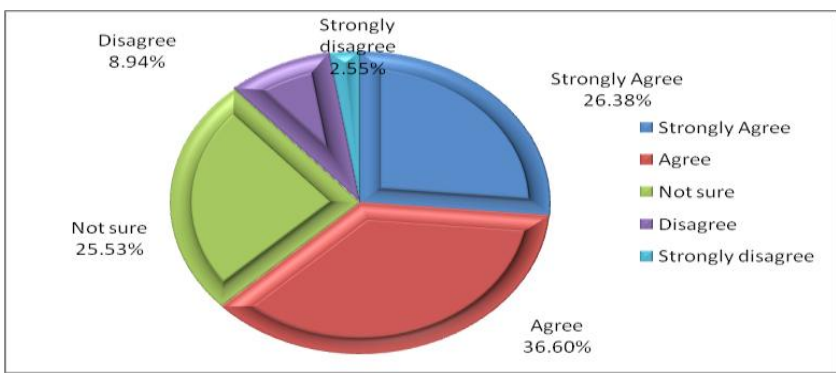

Chart 1.1 Responses of employees

\section{CHI-SQUARE Test}

To find out the relationship between the experience of the respondents and the cross training improving the career growth of the respondents, the researcher has adopted the Chi-Square test to test the formulated hypothesis.

Hypothesis: $\mathrm{H} 0=$ The experienced respondents agree that the cross training is beneficial to employee career growth.

TABLE 1.2 THE EXPERIENCE OF THE RESPONDENTS AND THE Cross training Beneficial to CAREer Growth

\begin{tabular}{|c|c|c|c|c|c|c|}
\hline & \multicolumn{5}{|c|}{$\begin{array}{c}\text { Cross training beneficial to employer } \\
\text { career growth }\end{array}$} & $\begin{array}{l}\text { TOT } \\
\text { AL }\end{array}$ \\
$\begin{array}{c}\text { Experie } \\
\text { nce }\end{array}$ & $\begin{array}{l}\text { Strongly } \\
\text { Agree }\end{array}$ & Agree & $\begin{array}{l}\text { Not } \\
\text { sure }\end{array}$ & $\begin{array}{l}\text { Disa } \\
\text { gree }\end{array}$ & $\begin{array}{l}\text { Strong } \\
\text { ly } \\
\text { disagr } \\
\text { ee }\end{array}$ & \\
\hline $\begin{array}{c}1-10 \\
\text { years }\end{array}$ & 41 & 50 & 15 & 7 & 2 & 115 \\
\hline $\begin{array}{c}11-20 \\
\text { years }\end{array}$ & 38 & 34 & 8 & 9 & 4 & 93 \\
\hline $\begin{array}{c}21-30 \\
\text { years }\end{array}$ & 11 & 11 & 1 & 0 & 2 & 25 \\
\hline $\begin{array}{l}31-40 \\
\text { years }\end{array}$ & 2 & 0 & 0 & 0 & 0 & 2 \\
\hline $\begin{array}{l}\text { Above } \\
40 \text { years }\end{array}$ & 0 & 0 & 0 & 0 & 0 & 0 \\
\hline Total & $\mathbf{9 2}$ & $\mathbf{9 4}$ & $\mathbf{2 5}$ & $\mathbf{1 6}$ & $\mathbf{8}$ & $\mathbf{2 3 5}$ \\
\hline
\end{tabular}

Chi -Square Analysis

$\mathrm{Eij}=(\mathrm{Ti} X \mathrm{Tj}) / \mathrm{N}$

$\sum[(\mathrm{O}-\mathrm{E}) 2 / \mathrm{E}]=11.908$

Calculated Value $=11.908$

Degree of freedom to find the tabulated value

$$
\begin{aligned}
& =(\mathrm{r}-1)(\mathrm{c}-1) \\
& =(5-1)(5-1) \\
& =16
\end{aligned}
$$

Degree of freedom $=16$

Tabulated value at $5 \%$ level of significance for Degrees of freedom $=26.296$

Calculated value $<$ Tabulated Value

$$
11.908<26.296
$$

\begin{tabular}{|c|c|c|c|c|}
\hline$\frac{\text { Observe }}{\mathrm{d}(\mathrm{O})}$ & $\begin{array}{l}\text { Expecte } \\
\text { d (E) }\end{array}$ & $\underline{\text { O-E }}$ & $(\mathrm{O}-\mathrm{E})^{2}$ & $\frac{(\mathrm{O}-\mathrm{E})^{2} l}{\mathrm{E}}$ \\
\hline 41 & 45.02 & -4.02 & 16.16 & 0.36 \\
\hline 50 & 46 & 4 & 16 & 0.35 \\
\hline 15 & 12.23 & 2.77 & 7.67 & 0.63 \\
\hline 7 & 7.83 & -0.83 & 0.69 & 0.09 \\
\hline 2 & 3.91 & -1.91 & 3.65 & 0.93 \\
\hline 38 & 36.41 & 1.59 & 2.53 & 0.07 \\
\hline 34 & 37.2 & -3.2 & 10.24 & 0.27 \\
\hline 8 & 9.89 & -1.89 & 3.57 & 0.36 \\
\hline 9 & 6.33 & 2.67 & 7.13 & 1.12 \\
\hline 4 & 3.16 & 0.84 & 0.7 & 0.22 \\
\hline 11 & 9.78 & 1.22 & 1.49 & 0.12 \\
\hline 11 & 10 & 1 & 1 & 0.1 \\
\hline 1 & 2.66 & -1.66 & 2.75 & 1.03 \\
\hline 0 & 1.7 & -1.7 & 2.89 & 1.7 \\
\hline 2 & 0.85 & 1.15 & 1.32 & 1.55 \\
\hline 2 & 0.78 & 1.22 & 1.49 & 1.91 \\
\hline 0 & 0.8 & -0.8 & 0.64 & 0.8 \\
\hline 0 & 0.21 & -0.21 & 0.04 & 0.21 \\
\hline 0 & 0.14 & -0.14 & 0.02 & 0.14 \\
\hline 0 & 0.068 & -0.068 & 0.004 & 0.068 \\
\hline 0 & 0 & 0 & 0 & 0 \\
\hline 0 & 0 & 0 & 0 & 0 \\
\hline 0 & 0 & 0 & 0 & 0 \\
\hline 0 & 0 & 0 & 0 & 0 \\
\hline 0 & 0 & 0 & 0 & 0 \\
\hline
\end{tabular}

Table 1.3 The Experience of the respondents and the Cross-training benefits to employee career growth - Statistical Calculation.

From the above calculations it is analysed thatthe above hypothesis is accepted. Thus, experienced respondents accept that cross training is beneficial to employee career growth

\section{Findings}

- 2.55 percent of respondents strongly disagree that the cross training is beneficial to employee career growth.

- 8.94 percent of respondents disagree that the cross training is beneficial to employee career growth.

- 25.53 percent of respondents are not sure that the cross training is beneficial to employee career growth.

- 36.60 percent of respondents are agreeing that the cross training is beneficial to employee career growth and 26.38 percent of respondents strongly agree that the cross training is beneficial to employee career growth.

- It is observed that majority of the respondents agree that the cross training is beneficial to employee career growth. 


\section{SUGGESTIONS}

From the observations and findings it is suggested that, the employer should conduct the cross training programs to the eligible and interested employees which will help the employees to learn multiple skills and thus to grow in their career.

\section{RESULT AND CONCLUSION}

From this study it is shown that there is a positive relationship between cross training and employee career growth. Training has a positive impact on career prospects and it enhances the career opportunities of the employees to grow vertically. Employees will have better chances of promotion as they acquire multiple skills. The employees will get better understanding of their job roles as well as the other employees. Acquiring skillsdevelops the self-confidence of the employees. They will have better chances of getting promoted or getting assigned with more responsibilities thus making way for good salary increments. Their efficiency will be improved thus the productivity will also be increased.

It is concluded that the cross training makes the employees to acquire better work skills and they will contribute to improve the productivity which is helpful for the achievement of organizational goals and self-development with the knowledge of multiple skills which will help them to grow vertically in career.

\section{REFERENCES}

1) Amstrong, M. (2003), A hand book of human Resource Management,8thed. Free press.

2) Brown, D.S. \& Lent, R.W. (2005): Career Development and Counseling. Putting Theory and Research to work. New Jersey: John Wiley \& Sons.

3) Bowman, S. A. \&Hottenstein, M. P. (1998). Cross-training and worker flexibility: a review of DRC system research. Journal of High Technology Management Research, 2, p. 157.

4) Campell, G. M. (1999). Cross-training of workers whose capabilities differ. Management Science, 5, p. 722.

5) Dekker, R., De Grip, A., \&Heijke, H. (2002). The Effects of Training and Overeducation on Career Mobility in a Segmented Labour Market. International Journal of Manpower, 23(2), 106-125.

6) Wexley, K. N. (1981) Developing and Training Human Resources in Management Academy of Management Journal, v37, (6), p1518-1542.

7) https://theuncommonleague.com/blog/20171128/benefits-of-cross-tr aining-in-business-builds-strong-teams-and-versatility, Paul Crosby, November 28, 2017

8) https://www.therightstaff.com/2015/02/20/six-benefits-of-cross-train ing-employees/

9) https://hrdailyadvisor.blr.com/2018/10/12/what-are-the-downsides-o f-cross-training-employees/ 